\title{
ARTE, GUERRA Y FIESTA EN LA BAJA EDAD MEDIA: APROXIMACIÓN A LA RELACIÓN ENTRE LA POLIORCÉTICA Y EL FASTO CABALLERESCO
}

\author{
ART, WAR AND FEAST IN THE LOW MIDDLE AGES: \\ APPROXIMATION TO THE RELATIONSHIP BETWEEN \\ POLIORCETICI AND CHIVALRIC PAGEANT
}

\author{
Carmen Vallejo Naranjo \\ Grupo de Investigación HUM-429: Museum \\ cvallejo@us.es
}

En la Baja Edad Media, la caballería ocupó con plena madurez el papel político-militar al que había ido accediendo como máximo estamento civil. La imagen lúdica de la institución se incorporó a su repertorio iconográfico representativo y el fasto caballeresco, como producción artística, se convirtió en el medio de expresión estética por excelencia de la fiesta tardogótica. Presentamos este episodio interdisciplinar entre el medio guerrero y el precortesano del estamento caballeresco y su cultura de la guerra, a través de la reutilización de materiales, estructuras y estrategias militares con tratamiento y finalidad artística que las fuentes gráficas y escritas nos ofrecen.

Palabras clave: arte; caballería; fiesta; guerra; poliorcética.

In the late Middle Ages, chivalry fully assumed the political-military role which it had gradually attained as supreme civil class. The ludic imagery of this institution was incorporated into its representative iconographic repertoire and chivalric pageantry, considered as an artistic production, became par excellence the means of aesthetic expression of late Gothic festivals. This paper presents an interdisciplinary episode dealing with both chivalry's warlike and pre-courtly means and culture of war through the artistically purposed reuse of materials, structures and military strategies provided by graphic and written sources.

Keywords: Art; chivalry; feast; war; poliorcetici. 
En la Baja Edad Media, guerra y fiesta son los polos que marcan el pulso de la vida colectiva. Para el estamento nobiliario y bajo ordo caballeresco, ambas, son expresiones de poder y, ambas, se ejecutan con un fuerte y depurado código ideológico y estético. Tanto en el medio guerrero como en el lúdico-deportivo, la caballería como institución y el caballero como aristócrata se justifican y representan funcional, estamental, económica y políticamente a través del ejercicio de su oficio, convirtiéndose en las dos caras de su imagen pública. Bajo esta nueva y última identidad, se utilizará de forma legítima y ambivalente parte del material de guerra para recrear durante la fiesta estructuras arquitectónicas y simulacros de estrategias bélicas bajo una fuerte dramatización escénica, convirtiendo al fasto caballeresco en la máxima expresión cortesana de su ancestral cultura laica, guerrera y varonil.

Para contextualizar mínimamente la importancia del fasto caballeresco, dentro del ámbito general de la fiesta en la cultura medieval europea ${ }^{1}$, debemos señalar someramente la funcionalidad de los principales pilares en los que se asienta: guerreros, económicos, sociopolíticos y culturales, hasta introducirse en la Edad Moderna como el último recurso estético de representación pública del estamento. La fuerte cultura bélica germana de naturaleza mercantil, convirtió la guerra en el modo de vida que marcó la existencia humana en la Edad $\mathrm{Media}^{2}$. La Iglesia comenzó en el siglo XI su proceso de reforma y expansión frente al Imperio Germano por la preeminencia del poder terrenal, presentando a la caballería como el brazo armado de la nueva iglesia militante bajo órdenes directas del papado: la militia sancti Pe$\mathrm{tri}^{3}$. En este complejo contexto se enmarca el comienzo del dilatado conflicto denominado como Querella de las investiduras (1075) y el movimiento de las Cruzadas que junto con la Pax et tregua Dei ${ }^{4}$ fueron proclamados en el Concilio de Clermont

${ }^{1}$ LADERO QUESADA, Miguel Ángel: Las fiestas en la cultura medieval. Barcelona, 2004; y LADERO QUESADA, Miguel Ángel: Las fiestas en la Europa Medieval. Madrid, 2015.

${ }^{2}$ CONTAMINE, Philippe: La guerra en la Edad Media. Barcelona, 1984, pp. 232-341.

${ }^{3}$ El concepto de militia sancti Petri fue introducido por León IX (1049-1057) en las campañas de defensa de los territorios de la Iglesia. Alejandro II (1061-1073) lo aplicó a nuestra Reconquista y, en el contexto de la Querella de las investiduras, junto con su sucesor Gregorio VII (1073-1085), contra la simonía.

${ }^{4} \mathrm{La}$ "Paz de Dios" protegía a los indefensos: eclesiásticos, mujeres y niños, campesinos, peregrinos y bienes públicos -molinos, iglesias, cosechas o animales de tiro-. La "Tregua de Dios" prohibía luchar en Adviento, Cuaresma, Pascua, en invierno, de noche o si llovía, y desde el viernes por la tarde hasta el lunes por la mañana. Su quebrantamiento estaba duramente perseguido por el "Tribunal de la Paz" con severas penas físicas -amputaciones de miembros- y espirituales -excomuniones, maldiciones y expulsiones de la Iglesia-. 
$(1095)^{5}$. Salvando este ámbito general para la Cristiandad, la tregua tenía el mismo marco jurídico y escala que las partes en conflicto, siendo, en realidad, y dependiendo del tipo de lucha, un simple pacto colectivo o personal de ámbito local ${ }^{6}$. Se apeló al concepto del otium onestum para canalizar la actividad de la caballería en los períodos de tregua en los que el negocio se suspendía y el desorden imperaba, incidiendo en la responsabilidad moral del caballero de mantener sus aptitudes físicas y psíquicas intactas y prestas para el combate ${ }^{7}$. Hasta principios del siglo XIV, todo ello se mantuvo como un código moral dentro de la institución, pues los torneos fueron condenados por el papado desde el siglo XI y canónicamente en el Corpus Iuris canonici de Gregorio IX en 1234, prohibiendo cristiana sepultura a los caballeros caídos durante su ejercicio y excomulgando a los participantes ${ }^{8}$. El papa Juan XXII levantó la prohibición en 1316 y, pocos años después, comenzaron las fundaciones de las órdenes curiales europeas, correspondiendo la primacía a la castellana Orden de la Banda en $1332^{9}$.

En Castilla, como frontera meridional de la última Cruzada, esta apelación al ocio honesto se mantuvo como un recurso de legitimación guerrera hasta la caída del reino de Granada. Los "caballeros leídos” siempre justificaron en sus obras su

${ }^{5}$ CONTAMINE, Philippe: La guerra en la Edad Media, op. cit., pp. 340-344.

6 ALFONSO X, EL SABIO: Las Siete Partidas, Partida VII, Título XII, Capítulo I. Madrid, 1994, p. 926.

${ }^{7}$ LLULL, Raimond: Libro de la orden de caballería, II, 10. Madrid, 1986, p. 33: "El caballero debe cabalgar, justar, correr lanzas, ir armado, tomar parte en torneos, hacer tablas redondas, esgrimir, cazar ciervos, osos, jabalíes, leones, y las demás cosas semejantes a éstas que son oficio de caballero; pues por todas estas cosas se acostumbran los caballeros a los hechos de armas y a mantener la orden de caballería. Por ello, menospreciar la costumbre y el uso de aquello por lo que el caballero aprende a usar bien de su oficio, es menospreciar la orden de caballería".

${ }^{8}$ ALFONSO X, EL SABIO: Las Siete Partidas, I, XIII, 10, op. cit., p. 125: "Torneo es una manera de uso de armas que hacen los caballeros, [...] e acaece, a las veces que mueren algunos de ellos. E para esto vedar más firmemente, puso por pena a los que entrasen en el torneo e allí muriesen que los no soterrasen en el cementerio con los otros cristianos, aunque se confesasen e recibiesen el cuerpo de Dios. E esto mandó para que los hombres tomasen escarmiento, en los que viesen soterrar por los campos, e se guardasen de lo hacer".

9 NÚÑEZ DE VILLASÁN, Juan: Crónica del muy esclarecido Príncipe y Rey don Alonso el onzeno... Cap. CXLIIII. Toledo, 1595, p. LXXXV: "Este Rey don Alonso de Castilla y de Leon como quiera que en aquel tiempo estuuiesse sin guerra, siempre se trabajaua en officio de caualleria haziendo torneos, y poniendo tablas redondas, y justando, y quando esto no hazia corria monte, y por esto, y otro si, porque los caualleros no pudiessen desusar las armas, y también que estuuiessen apercebidos para la guerra quando menester le fuesse, citando en Valladolid mando llamar por sus cartas los caualleros de la vanda, y otros caualleros y escuderos hijos dalgo de su reyno que fuesen todos en vno con el en aquella villa dende a tercer dia antes del dia de pascua, y truxessen alli todos sus caballos y sus armas, y para aquel dia que el rey los embio a llamar vinierõ alli todos". 
prolija actividad literaria como ocio honesto ${ }^{10}$. Don Juan Manuel (1282-1348) defiende su producción literaria como utilización provechosa de su tiempo de ocio frente a la habitual conducta pendenciera de la caballería ${ }^{11}$. En realidad, la cultura caballeresca y la formación de sus miembros, juega un papel esencial en la transmisión de la cultura laica bajomedieval. El discurso ideológico de la caballería $^{12}$ es el único instrumento de autoridad con el que la monarquía y la alta aristocracia feudal se expresan lejos de las armas. Mantiene viva la exégesis de materias y conceptos capitales que son la base de la tratadística de género doctrinal castellana, como credo seglar para la propia institución y para la formación del Príncipe hasta las mismas puertas de la Edad Moderna.

Los factores fundamentales que en el espacio cultural de la fiesta caballeresca justifican y legitiman públicamente la actividad del caballero durante el impás bélico de la tregua dada, reflejan claramente los cambios sociales que promueven los intereses de la nueva clase nobiliaria y su monarquía. Esta, dirigirá el último proceso de canalización colectiva de los ancestrales usos e intereses guerreros de la institución como medio de vida hacia un ejercicio propagandístico de la imagen y el programa político regio. Lo que supone la consagración definitiva del medio cortesano como marco de la función política que la caballería está llamada a desempeñar. En definitiva, la evolución de la fiesta caballeresca está intrínsecamente ligada a la propia progresión de la monarquía medieval hacia el absolutismo moderno.

Todo ello se hará sin perder su génesis guerrera, pues la función del torneo y demás ejercicios caballerescos, como medio de entrenamiento físico y militar, continuaba plenamente vigente. El entrenamiento durante el tiempo de ocio no era solo una cuestión de supervivencia para la batalla. Los caballeros también se entrenan para la fiesta, ofrecen el máximo espectáculo, son los deportistas de élite del medioevo y detrás de ello hay, de modo natural, un fuerte componente económico. Para el estamento aristocrático, cuyos privilegios se sostienen

${ }^{10}$ MARQUÉS DE SANTILlANA: Obras completas. Madrid, 2003, p. 487; GARCÍA DE CASTROJERIZ, Juan: Glosa al Regimiento de Príncipes de Egidio Romano, III, III, VII. Madrid, 1947, pp. 329-333; SÁNCHEZ DE ARÉVALO, Rodrigo: Vergel de los príncipes. Madrid, 1959, p. 314; y DE VALERA, Diego: Espejo de verdadera nobleza. Madrid, 1959, p. 89.

${ }^{11}$ DON JUAN MANUEL: Libro infinido. Cap. XXVI, Vol. I. Madrid, 1982, pp. 182183: “[...] Et commo quier que yo se [que] algunos profaçan de mi porque fago libros, digo vos que por eso non lo dexaré, [...] Et pues en los libros que yo fago ay en ellos pro et verdad et non danno, por ende non lo quiero dexar por dicho de ninguno. [...] Ca deuedes saber que todas las cosas que los grandes sennores fazen, todas deuen ser guardando primera mente su estado et su onra, mas esto guardado, quanto mas a[n] en si de vondades, tanto son mas conplidos. [...] et pienso que es mejor pasar el tienpo en fazer libros que en iugar los dados o fazer otras uiles cosas".

${ }^{12}$ RODRÍGUEZ VELASCO, Jesús: El debate sobre la caballería en el siglo XV. La tratadística caballeresca castellana en su marco europeo. Valladolid, 1996. 
exclusivamente mediante la función guerrera, la tregua suponía una merma en sus ingresos, necesarios para mantener el equipo y nivel de vida al que legalmente obligaba el estatus de caballero ${ }^{13}$. La inversión económica en formación y equipo, el pago de rescates de la varonía de la casa y la ostentación mal entendida de la largesse aristocrática podían llevar a la decadencia de un linaje ${ }^{14}$. En Castilla, se compensaba el perjuicio económico que todo ello suponía, liberando de tributar a las arcas regias o señoriales el quinto del botín obtenido durante estos encuentros caballerescos, como era obligatorio hacer con el botín de guerra ${ }^{15}$.

En definitiva, la fiesta caballeresca sostenía su propia red de intereses, ofreciendo la posibilidad de obtener de modo legítimo beneficios propios y de distinta índole que seleccionaba y jerarquizaba al propio estamento aristocrático en baja, media y alta aristocracia. Los grandes señores, incluidos reyes y príncipes, que no perseguían el botín porque estaba mal visto y cuyo único afán era no dejarse $\operatorname{apresar}^{16}$, se veían en la obligación de patrocinar grandes festejos que estuvieran a la altura de su estatus social. Debían sufragar tanto la organización técnica del torneo y el mantenimiento del equipo mantenedor -armamento, manutención, transporte y alojamiento de todo su séquito y servicio, etc.- como todo el boato -fiestas, banquetes y agasajos a las damas, invitados y equipo aventurero-. Este derroche de medios económicos se sumaba a los gastos permanentes de la estructura militar y hacendística de sus dominios. Para los jóvenes caballeros la fiesta suponía el medio natural de ascenso social donde conseguir prestigio y fortuna. Además de gozar de los deleites del amor, se introducían en la vida amable de la Corte, buscando poseer el favor de la "Señora"17 que les buscaba matrimonios ventajosos para ellos ${ }^{18}$.

${ }^{13}$ ALFONSO X, EL SABIO: Las Siete Partidas, II, XXI, 12, op. cit., p. 291. El trabajo manual o mercantil y la pobreza son acciones y condiciones excluyentes para el ingreso o permanencia en el orden caballeresco.

14 VALE, Malcolm: War and Chivalry. Londres, 1981, p. 14.

15 ALFONSO X, EL SABIO: Las Siete Partidas, II, XXVI, 18, op. cit., p. 335: "Mas el torneamiento que se hace por razón de usar las armas, e no por matarse ni por otra enemitad que los hombres hubiesen unos con otros, tal como éste con todo lo que allí ganase debe ser suyo, e no ha de partir con ninguno, ni dar quinto ni derecho al rey ni a otro señor que haya".

16 DUBY, Georges: Guillermo el Mariscal. Madrid, 1997, pp. 156-157.

${ }^{17}$ KEEN, Maurice: La caballería. Barcelona, 1986, pp. 49-51. Define la situación "doméstica" como un eufemismo del vasallaje hacia el señor reflejado en su esposa de índole ideal, menos carnal. DUBY, Georges: Los tres órdenes o lo imaginario del feudalismo. Barcelona, 1985, p. 394; y DUBY, Georges: Guillermo el Mariscal, op. cit., p. 76. Sostiene que el señor feudal presenta a la dama como un señuelo de distracción sexual para controlar a los jóvenes de su casa.

18 CHACÓN, Gonzalo: Crónica de don Álvaro de Luna. Condestable de Castilla. Cap. VII. Madrid, 1940, p. 26: “[...] e fabló con algunos grandes de la corte quexándose de aquel 
En el nuevo contexto cortesano, el famoso caballero borgoñón Godofredo de Charny en su Livre de Chevalrie (1350) versa sobre el amor cortés y lo presenta, junto con el honor caballeresco, como los acicates que avivan fuertemente el valor del caballero. El recuerdo de la amada, el miedo a decepcionarla y el íntimo deseo de poseerla lo impulsarán a luchar hasta la extenuación. La fiesta caballeresca se establecía como el marco lúdico por excelencia donde se desarrollará públicamente este nuevo código de las relaciones intersexos. Un cortejo amoroso donde el varón llama la atención de la amada, exhibiéndose con sus ricas galas, demostrando su virilidad por medio de la violencia, como fuerte reclamo de promesa erótica, o dilatando voluntariamente la consecución del encuentro final a través de un voto que dificulte y ennoblezca la obtención de tan preciado botín. El amor cortés se convertía así, en la esencia del misticismo laico caballeresco. Este alarde de control sexual alegoriza la continua lucha interna del caballero por dominar su pathos y, por tanto, pertenece también a su propio proceso de formación. Pero, en la mayoría de los casos, la relación amorosa no era tan sutil y la recompensa se sabía mucho más explícita e inmediata. En el fondo, esta épica erótica del amor cortés enmascara bellamente la pulsión viril más carnal, aquella que finalmente lo rinde vasallo de la plenitud femenina, madre-amante, como la fuerza que mueve el mundo.

Todos estos factores están inscritos dentro del concepto antropológico de la fiesta. No es una cuestión ni parcial, ni secundaria, puesto que este producto y ostentación estética de la cultura caballeresca es, al mismo tiempo, recreación y ejercicio del poder adonde se traslada la intriga y la tensión de las luchas entre bandos políticos ${ }^{19}$. Esta imagen pública de la verdadera jerarquía local del

fecho, e diziendo «que se tenía por muy desdichado por la Reyna aver querido tener aquella manera con él, siendo él un caballero pobre, e tanto moço, e quererlo ella trabar con una donzella pobre tan prestamente»".

19 LÓPEZ DE AYALA, Pedro: Crónica de los Reyes de Castilla... Madrid, 1910, Año IV, Cap. III, p. 429 y Cap. VI, p. 432. Año V, Cap. XVII, p. 446; PÉREZ DE GUZMÁN, Fernán: Generaciones, semblanzas... Madrid, 1877, Año XVII, Cap. III, p. 424. Año XXII, Cap. X, p. 447 y Año XXVIII, Cap. IV, p. 516; DÍEZ DE GAMES, Gutierre: El Victorial. Salamanca, 1997, Cap. LI, p. 434; CHACÓN, Gonzalo: Crónica de don Álvaro de Luna. Condestable de Castilla. Cap. XIV, op. cit., p. 53; VALERA, Diego de: Memorial de diversas hazañas. Madrid, 1941, Cap. X, pp. 36-37: “[...] y dende se fué para Sevilla, donde estuvo algunos dias con la reyna su muger. Donde se fizieron grandes justas y torneos, en el qual se creyó que viniera alguna turbación, por las competencias que avía entre el duque de Medinasidonia y el marqués de Villena; y ese día estuvo armada muy gran parte de la gente de la çiudad, y aun el rey vino al torneo trayendo coraças vestidas y casquete en la cabeça, y plugo a Nuestro Señor que las cosas se metiguaran. En este torneo fueron capitanes de la vna parte el duque de Medinasidonia, en cuya parte venía Miguel Lucas, que ya parescía contender de parcialidad con el marqués de Villena, y de la otra parte el marqués de Villena”. 
poder medieval, convierte el fasto caballeresco en un elemento esencial del ejercicio político regio como medio de reafirmación ante la siempre amenazadora aristocracia y como medio de proyección de una idea tangible de sí misma ante la población. Por su alto contenido ideológico y estético quedaron plenamente enmarcadas en el ceremonial regio de las curialis disciplinae ${ }^{20}$, sin detrimento de la representación institucional y personal de la caballería ${ }^{21}$. El ceremonial y el nivel de ostentación aristocrático se complicaron tanto que provocó la denuncia de algunos miembros del estamento por la pérdida de sus contenidos ideológicos, recurriendo a los tópicos literarios del Ubi sunt ${ }^{22}$ y la Edad de Oro de la idealizada caballería romana ${ }^{23}$. Estudiada su trascendencia, se defiende el recurso escenográfico como una actividad cultural de primer orden, cuyo objetivo es entretener, instruir y proyectar la imagen pública de la caballería y de sus valores desde un marco idealizado, frente al resto de celebraciones cívicas, a través de la rica mitología pseudohistórica caballeresca. Lo que produjo el éxito y profundo arraigo cultural del torneo en la Baja Edad Media, pues el impacto que las fuentes literarias tuvieron sobre una clase guerrera recién llegada a la cultura cortesana provocó que los caballeros quisieran vivir el ritual de esa épica literaria de ficción ${ }^{24}$. La naturaleza competitiva, amorosa y novelesca de las fiestas de caballería se hacía realidad en ellas mismas ${ }^{25}$. Los excesos grandilocuentes serían parte del vocabulario propagandístico del poder regio necesitado de perpetuar en la memoria colectiva los costosos festejos realizados. En definitiva, la fiesta tardogótica caballeresca celebraba su propia existencia como grupo humano, recogía su tradición funcional más ancestral que la cohesionaba y, al mismo tiempo, integraba los últimos acontecimientos políticos regios y culturales como reflejo de todo lo que bullía dentro de la nueva entidad urbana ${ }^{26}$.

${ }^{20}$ NIETO SORIA, José Manuel: Ceremonias de la Realeza. Propaganda y legitimación en la Castilla trastámara. Madrid, 1993, p. 167.

${ }^{21}$ DE ANDRÉS DÍAZ, Rosana: "Las fiestas de caballería en la Castilla de los Trastámaras", La España medieval, 5, 1986, pp. 81-84.

${ }^{22}$ MANRIQUE, Jorge: Coplas, Estrofas XVI y XVII, vv. 181-204. “¿Qué se hizo el rey don Joan? Los infantes d'Aragón ¿qué se hizieron? ¿Qué fue de tanto galán, qué de tanta invinción como truxeron?...”.

${ }^{23}$ GARCÍA DE CASTROJERIZ, Juan: Glosa al Regimiento de Príncipes de Egidio Romano, III, III, VIII, op. cit., pp. 334-339.

${ }^{24}$ KEEN, Maurice: La caballería, op. cit., pp. 126 y 256-286; y OLEZA, Joan: "Las transformaciones del fasto medieval", en Teatro y espectáculo en la Edad Media. Alicante, 1992, pp. 47-64.

${ }^{25}$ DE ANDRÉS DÍAZ, Rosana: "Las fiestas de caballería en la Castilla de los Trastámaras", op. cit., pp. 89-93.

${ }^{26}$ CARDINI, Franco: "La feste in toscana tra medioevo ed Età Moderna", Incontri Pistoiesi di storia, arte e cultura, 38, 1987, pp. 2-3. 
La necesidad e importancia de todos estos aspectos señalados, justifican plenamente la profusión de medios económicos, técnicos y artísticos puestos al servicio de la fiesta caballeresca que se constituye en el tiempo y espacio estético de la institución. Las fuentes gráficas y escritas nos informan de una nómina de estructuras o construcciones de carácter efímero, levantadas para el buen desarrollo y máxima espectacularidad de la misma. El fasto caballeresco se desarrolla en ámbitos espaciales y tiempos diversos porque promueve manifestaciones de temáticas distintas, tanto dinámicas como estáticas, que demandan escenarios polivalentes. Espacios abiertos y públicos para los encuentros lúdico-deportivos y espacios cerrados y privados para los actos de representación aristocrática de sus anfitriones. La convocatoria se realizaba con meses de antelación. Los capítulos declaraban la ideología del festejo, la modalidad, sus condiciones y el equipo mantenedor. Si se desarrollaba plenamente intramuros, el espacio urbano era el escenario público de la fiesta que confluía en la plaza, generalmente la del mercado $^{27}$. Mientras que los espacios arquitectónicos privados celebraban y hospedaban a sus participantes. En espacio privado se desarrollaba la recepción de los equipos, los agasajos a las damas, banquetes, bailes, etc. y, por último, la deliberación y coronación del campeón. Toda esta actividad programada se denomina en las fuentes "hacer sala". De ser celebrado extramuros, la arquitectura efímera debía recrear este espacio arquitectónico y urbanístico permanente a base de madera y textiles. El número de elementos y grado de riqueza de sus materiales privilegia el nivel del evento y de su anfitrión. El emperador Federico I, Barbarroja, en 1184, levantó una verdadera ciudad efímera a orillas del Rin para los invitados a la investidura de armas de sus dos hijos ${ }^{28}$. Estas "ciudades" de ricos pabellones eran utilizadas igualmente en los campamentos militares. Carlos, el Temerario, duque de Borgoña, en el sitio de Neuss (1473-1474), levantó un campamento con tal pompa cortesana que algunos de sus señores alzaron, para su esparcimiento, pabellones en formas de castillos, con galerías internas y jardines a su alrededor ${ }^{29}$. Ya en el siglo XVI, el hito de este capítulo lo constituye El campo del paño de oro ${ }^{30}$ (Figura 1). La cualidad suntuaria tenía en el contexto militar idéntica función de ostentación, identificación y jerarquización del poder guerrero-nobiliario -también ante el enemigo-. Nada de ello estaba reñido con su ancestral y necesaria

${ }^{27}$ FERRER VALLS, Teresa: "El espectáculo profano en la Edad Media: espacio escénico y escenografía”, en Historias y ficciones: Actas del coloquio sobre la literatura del siglo XV. Valencia, 1992, pp. 307-322.

${ }_{28}$ KEEN, Maurice: La caballería, op. cit., p. 39.

${ }^{29}$ HUIZINGA, Johan: El Otoño de la Edad Media. Madrid, 1978, p. 138.

${ }^{30}$ Evento diplomático de gran pompa caballeresca, celebrado cerca de Calais en 1520 para pactar una tregua entre Francisco I de Francia y Enrique VIII de Inglaterra. De la riqueza en los paños de los pabellones toma su nombre. 
planimetría regular castrense y su capacidad histórica para trascender en ciudades permanentes ${ }^{31}$. Aunque, en la necesaria esquematización narrativa de las ilustraciones medievales, para indicar su gran número se muestre un mar de agolpados pabellones. En ambos casos, el militar y el festivo, tanto las fuentes gráficas como las escritas hacen hincapié en la funcionalidad espacial, la complejidad de algunas de sus estructuras y la representación de rango que ofrecen. Finalmente, durante la liza se colocaba un pabellón en cada lado menor del campo con el blasón del participante y servían para terminar de armarse y desarmarse o descansar, si el rey de armas así lo indicaba ${ }^{32}$.

Las distintas estructuras que delimitaban el campo y acogían al aforo, para conseguir el alto grado de fastuosidad que la fiesta requería, se revestían con ricos paños cuyo uso era exclusivo de la aristocracia. Los tejidos eran el medio por excelencia del tratamiento suntuario medieval, tanto en los espacios urbanos como en los arquitectónicos, permanentes o efímeros y su valor crematístico es bien conocido. Las fuentes también testimonian el monopolio que sobre el maderamen tenía la institución caballeresca ${ }^{33}$.

Existen dos cercados, uno en la guerra y otro en la fiesta, que podría decirse tienen "jurisdicción” propia. El palenque delimitaba el campo de juego y estaba rodeado por un corredor o patín donde los escuderos se movían atentos a las evoluciones de sus señores y donde, también estos, desarrollaban las suertes de a pie. Sus dimensiones no estaban reglamentadas y oscilan en las fuentes ${ }^{34}$. Dentro de esta demarcación la máxima autoridad era el rey de armas que arbitraba y controlaba los tiempos de los encuentros. Dependiendo de la magnificencia de

${ }^{31}$ CHUECA GOITIA, Fernando: Breve historia del urbanismo. Madrid, 2000, pp. 58, $62-63$ y 108.

32 CARRILlO DE HUETE, Pedro: Crónica del halconero de Juan II de Castilla. Vol. III, Cap. VII. Madrid, 1946, pp. 26-27: "E la liza donde hicieron el canpo fue en el corral de San Pablo de Valladolid. E fue muy ordenada, de sus palenques doblados, e de dentro su patín para pie, al pie de donde estavan los cadalsos donde mirava el señor Rey. E las armas fueron en esta guisa: una tela puesta en mitad de la liza, e a las dos esquinas dos tiendas. E ellos vinieron ay con cada tres pajes bien rricos, e sus estandartes, e con muchos farautes e menestrales e trompetas. E llegaron así a la liza, e llegaron a fazer rreverencia al Rey, e fue cada uno para su tienda, e armáronse. E luego salieron armados e con escudos de azero. E la condición de las armas era que fiziesen tantas carreras; [...] E luego quitaron los padrinos, e de ally volviéronlos a las tiendas, e desarmáronse".

33 DE VALERA, Diego: Preeminencia y cargos de los oficiales de armas. Madrid, 1959, p. 170: "y que la madera de los cadalsos y los cadalsos de las dichas liças fuesen dell oficio d'armas".

${ }^{34}$ DE VALERA, Diego: Tratado de armas. Madrid, 1959, pp. 119-121: "Las liças manda facer el rey de ochenta passos de largo e sesenta de ancho e altura acostumbrada de un codo". El autor está describiendo una liza francesa (111,5 x 83,6 x 0,42 m). 
la fiesta podía haber una desenfrenada actividad simultánea ${ }^{35}$ con más de un palenque activo, "palenques doblados" y juegos de precisión como la sortija o los bofordos ${ }^{36}$. En contexto bélico existía un cercado próximo al real llamado cuartel, coloquialmente "cuartel de la salud", porque en él se custodiaba durante la batalla la seguridad de los ilustres enemigos, presos o heridos, por los que se pediría un cuantioso rescate proporcionado a su abolengo. También llegaban a él buscando su "protección" los desertores del bando opuesto ${ }^{37}$. Su funcionalidad, como siempre en la guerra medieval, era económica y pactada. La guerra con cuartel era el medio habitual de obtener el botín sobre los rehenes. La batalla sin cuartel o campal era ya una solución extrema que pretendía terminar con un conflicto enquistado en el tiempo. El rehén quedaba sujeto tras juramento de vasallaje a su captor. Los rescates se pactaban y pagaban en varios plazos y una quinta parte se tributaba a la corona. Aún cuando el prisionero fuera liberado físicamente desde los primeros plazos, este no podía luchar contra el bando de su captor hasta no haber completado el pago.

En los lados mayores del palenque se levantaban los cadalsos o tribunas. En las fuentes gráficas se constata su exorno generalmente textil. Aunque, en alguna ocasión aparecen con cerramiento de madera y tratamiento decorativo en relieve que responderían a estaciones del año o climatologías más adversas, pues la vestimenta de sus ocupantes así lo indica. Son sencillas estructuras que asientan al egregio público y, por ello, al aventajado punto de observación va unida la necesaria seguridad del grupo humano que alojan, incluida la familia real. Es decir, requieren un probado cálculo de estructuras para el aforo previsto que no puede improvisarse (Figura 2). La jerarquía estamental y organizativa se escenificaba ubicando a los anfitriones y sus invitados más ilustres en los cadalsos centrales al campo, flanqueados por otros donde se alojaba el resto de la aristocracia. También, se organizaban por sexos, quedando la reina y sus damas en un cadalso y el rey y sus caballeros en otro. Los cadalsos desarrollados en altura reservaban la más alta para el rey, duques, condes y caballeros. La intermedia para el valido y los cortesanos y la baja para los oficiales de $\operatorname{armas}^{38}$. La mención en las crónicas

${ }^{35}$ PÉREZ DE GUZMÁN, Fernán: Generaciones y Semblanzas... Año XXXIV, Cap. XIV, op. cit., pp. 565-566.

${ }^{36}$ Estos juegos no requerían un contexto dramatizado con decorados o estructuras efímeras y se ejecutaban sin demarcación precisa (p.e.: Ms. Fr. 1436, ff.: 130v y 131v de la B.N.F.). Los bofordos eran muy peligrosos para el público y Alfonso XI en el Ordenamiento de Alcalá (1348) legalizó la costumbre de llevar señales acústicas. Son los cascabeles cosidos a las gualdrapas de los caballos que se aprecian diez años antes en los jinetes del Libro de la Cofradía de Santiago de Burgos (1338), f. 21v. Estas prácticas no eran exclusivas de la caballería de linaje y la caballería villana se incorporaba al fasto local haciendo gala de su virtuosismo en el bofordar.

${ }^{37}$ DE RIQUER, Martín: Caballeros medievales y sus armas. Madrid, 1999, p. 22.

${ }^{38}$ DE VALERA, Diego: Tratado de armas, op. cit., p. 119. 
de la cantidad de cadalsos y su aforo da medida del prestigio del evento. Para la liza celebrada entre Diego de Guzmán y el famoso caballero borgoñón, Jacques Lalaing, se construyó un cadalso con capacidad para 103 caballeros y grandes señores de Castilla, Portugal, Navarra, Aragón y embajadores de Francia ${ }^{39}$. En la Sevilla de 1490, por la boda de la infanta Isabel con el infante Alfonso de Portugal, se levantaron en el compás de las atarazanas 100 cadalsos, cincuenta a cada lado del campo ${ }^{40}$. Se dieron otras soluciones, unas más funcionales, como la tribuna de tres gradas sobre plataforma móvil que aparece en el Torneo de mazas, fresco del luneto de la Sala de las Parejas del castillo Runkelstein (Italia) (Figura 3). Otras con estética más arquitectónica, pues con el apelativo de "palacios" las refiere Pedro del Corral en su particular "crónica de creación"

Debemos mencionar un vehículo que se incorpora a la fiesta caballeresca: el carro. Están relacionados intrínsecamente con el concepto más dinámico del cortejo y con el tratamiento temático más teatralizado de los juegos, que es una característica propia de este período. Forman parte del necesario impacto visual que toda entrada triunfal requiere como medio de ostentación escenográfica hacia el público y también sobre los contrincantes. Grandes carros ricamente aderezados, pues transportan al equipo ataviado con la temática escogida, grupos cantores o se reproduce alguna alegoría o escena en movimiento (Figura 4). Son las famosas rocas o castillos, pues a los castillos roqueros se les denominaba rocas ${ }^{42}$. También, participaban carros portando castillos de cuyas torres se prendían luminarias y fuegos artificiales y de ahí mantienen hoy su nombre ${ }^{43}$. Las mismas rocas o castillos que con escenografías religiosas y sufragadas por los gremios o los cabildos municipal y eclesiástico, se sumarán al cortejo del Corpus Christi, concretamente en

39 DE RIQUER, Martín: Caballeros andantes españoles. Madrid, 1967, p. 66.

${ }^{40}$ DEL PULGAR, Hernando: Crónicas de los Señores Reyes Católicos. Don Fernando é Doña Isabel de Castilla y Aragón. Tercera Parte, Cap. CXXVIII. Madrid, 1878, pp. 505506.

${ }^{41}$ DEL CORRAL, Pedro: Crónica Sarracina. Cap. XXXIII. Madrid, 2001, p. 185: "El Rey don Rodrigo mandó fazer fuera de la villa el río arriba unos palacios muy grandes a maravilla para quél e la Reina podiesen mirar, e muchas duquesas e grandes señoras dueñas e doncellas que eran venidas por ver esta fiesta que eran más de seis mil entre unas e otras; e fue fecho en poco tiempo".

${ }^{42}$ PÉREZ DE GUZMÁN, Fernán: Refundición de la Crónica de Juan II de Alvar $G^{a}$ de Santamaría. Año XXII, Cap. VIII. Madrid, 1877, pp. 446-447: "Pasada esta fiesta, el Rey de Navarra hizo otra en la forma siguiente: que mandó hacer una roca la qual levaba sobre carretones, y era tan grande que él venia dentro della armado de arnes real encima de un caballo muy grande é muy ricamente arredrado".

${ }^{43}$ FLORES ARROYUELO, Francisco J.: "La ciudad medieval como escenario. Primeras manifestaciones del teatro", Revista de Filología Románica, anejo III, 2002, pp. 59-60. 
Sevilla desde el siglo $\mathrm{XV}^{44}$. Son los carros abiertos de transporte de la maquinaria de guerra y de la infantería (Figura 5). Distintos de los famosos carros de combate husitas (1420), cerrados por batientes con troneras desde donde disparaban los ballesteros y que alineados en distintas formaciones, abiertas o cerradas, defendían como auténticas barreras móviles. Estrategia que se incorporó rápidamente a la defensa de los campamentos militares en forma radial (Figura 6).

\section{III}

Todavía quedan elementos que destacar y lo haremos a través de su función escenográfica, ya que no solo se realizaba una mera adecuación funcional de los medios bélicos a los festivos. La propia fiesta reproduce o alegoriza escenográficamente técnicas y tácticas de guerra defensivas y ofensivas. Los pasos de armas recrean la defensa de un itinerario crítico para la tropa, de un punto estratégico o un enclave fantástico. En ocasiones, se aprovecha la existencia de una construcción real, o en su ausencia, se recrea efímeramente.

El Passo Honroso de Suero de Quiñones se celebró en el año jubilar de 1434 entre el 10 de julio y 9 de agosto. El desafío se ubicaba en el puente de Órbigo, equidistante $25 \mathrm{~km}$ entre León y Astorga, en pleno camino francés de Santiago. Medio año antes, Suero pidió permiso e hizo voto ante Juan II de llevar al cuello todos los jueves una argolla de hierro en la que se leía su emblema en francés heráldico: "Si à voicés ne playst avoyr mesura, certes je di que je suys sans ventura" hasta quebrar trescientas lanzas por una "prisión de amor". Suero y nueve caballeros mantenedores, regidos bajo los veintidós capítulos leídos, quebrarían lanzas con todo caballero que osara pasar el puente con derecho mínimo de consumar tres carreras. Se debía luchar en arnés de guerra, más ligero pero más peligroso; de hecho, murió un caballero alemán de una entrada por la visera ${ }^{45}$. El campo de 146 pasos de largo $(203,4 \mathrm{~m})$ fue levantado en una floresta y dotado de siete cadalsos y veintidós pabellones en los que se abastecía de arnés a todo caballero que lo solicitase, lo que supone un altísimo capitulo económico. Nicolás Francés, maestro de la obra del retablo mayor de Santa María de Regla de León, realizó un faraute que con ademán señalizador indicaba el camino al

${ }^{44}$ LLEÓ CAÑAL, Vicente: Arte y Espectáculo: La fiesta del Corpus Christi en Sevilla en los siglos XVI y XVII. Sevilla, 1975; LLEÓ CAÑAL, Vicente: Fiesta Grande: El Corpus Christi en la historia de Sevilla. Sevilla, 1980; y ROMERO ABAO, Antonio del Rocío: "La fiesta del Corpus Christi", en Las fiestas de Sevilla en el siglo XV. Otros estudios. Madrid, 1991, pp. 93-94 y 97.

${ }^{45}$ PÉREZ DE GUZMÁN, Fernán: Generaciones y Semblanzas... Año XXVII, Cap. V, op. cit., p. 514. 
paso $^{46}$. Cumplimentadas las trescientas lanzas, Suero fue "liberado" y agasajado con sus compañeros por todo León. Su argolla adorna desde aquel año el cuello del relicario del cráneo de Santiago el Menor que se custodia en la capilla de las reliquias de la catedral de Santiago.

El Passo de la Fuerte Ventura ${ }^{47}$ formó parte del hito que suponen los festejos de mayo de 1428 en Valladolid. Ejemplo proverbial de la consagración del fasto caballeresco como marco del ejercicio político-diplomático del poder ${ }^{48}$. Fue el "campo de batalla estético" donde se expresó un amplio conflicto de intereses. De una parte, Juan II de Castilla y su restaurado valido don Álvaro de Luna y, de la otra, los infantes de Aragón ${ }^{49}$. Se celebraba la llegada de la infanta Leonor de Aragón camino de Portugal para su boda con don Duarte. El 18 de mayo don Enrique abrió los festejos con su paso de armas. El castillo estaba compuesto por una torre homenaje con cuatro torreones y un campanario central coronado con un pilar con un grifo ${ }^{50}$ tenante con sus armas. Estaba cercado con un lienzo de muralla con cuatro torres angulares que repetían a menor tamaño el mismo motivo heráldico de la central y otra cerca más baja o barrera con doce torres que albergaban una bella dama cada una. El desafío del paso se producía al cruzar

${ }^{46}$ RODRÍGUEZ DE LENA, Pedro: Libro del Passo Honroso defendido por el excelente cavallero Suero de Quiñones... Imprenta de Cornelio Bonardo. Salamanca, 1588, pp. 14-15: "Allende lo dicho se hizo vn faraute de marmol, obra de Nicolao Frances Maestre de las obras de S. María de Regla de Leon, y le assentaron sobre vn marmol bien adereçado de vestidos y de sombrero: puesta la mano siniestra en el costado, y tendida la mano derecha hazia do yua el camino Frances, en la qual estauan vnas letras que dezia: Por ay van al Passo. Fue puesto este faraute de piedra allénde la puente que dizen de $\mathrm{S}$. Marcos de la ciudad de Leon, en el camino Frances arredrado quanto sesenta passos de la puente: y fue acabado de poner alli con assaz de costa, sabado diez de Iulio que fue el primero dia de las justas".

${ }^{47}$ CARRILlO DE HUETE, Pedro: Crónica del halconero de Juan II de Castilla op. cit., pp. 19-27; BARRIENTOS, Lope: Refundición del halconero. Madrid, 1946, pp. 5867; GARCÍA DE SANTAMARÍA, Alvar: Crónica de Juan II de Castilla. Vol. C. Madrid, 1891, pp. 14-17; y PÉREZ DE GUZMÁN, Fernán: Refundición de la Crónica de Juan II de Alvar $G^{a}$ de Santamaría, op. cit., pp. 446-447.

${ }^{48}$ SUÁREZ FERNÁNDEZ, Luis: Nobleza y monarquía. Puntos de vista sobre la Historia política castellana del siglo XV. Valladolid, 1975, p. 105; y RUIZ, Teófilo: "Fiestas, torneos y símbolos de la realeza en la Castilla del siglo XV. Las fiestas de Valladolid de 1428", en Realidad e imágenes del poder. España a fines de la Edad Media. Valladolid, 1988, pp. 249-265.

49 PÉREZ DE GUZMÁN, Fernán: Refundición de la Crónica de Juan II de Alvar $G^{a}$ de Santamaría. Año XXII, Cap. VII, op. cit., p. 446: "El ynfante don Enrique fizo la primera fiesta, muy noble; el rey de Navarra, la segunda; e el rey de Castilla, la terçera, muy mayor e más noble que ninguna de las otras".

${ }^{50}$ El grifo era parte de la divisa de la Orden de Caballería de la Jarra y el Grifo fundada por Fernando I en 1403. 
un arco flanqueado por dos torres sobre el que se leía: "Este es el arco del pasaje peligroso de la fuerte Ventura". Esta construcción efímera reflejaba la intención propagandística del infante sobre la magnificencia de su Corte. La crónica otorga su autoría a un maestro lombardo al servicio de la casa de Aragón y pondera su calidad, tanto en el exterior: "paresçía de piedra", "paresçia fecho todo a cal y canto labrado", como en el interior, distribuyendo espacios habitables para personas y animales, y también de almacenaje. Tanto el uso político del fasto regio peninsular como su magnificencia artística en el siglo XV, no pueden entenderse sin la figura del infante Fernando, el de Antequera ( $† 1416)$, pilar póstumo de esta dinámica diplomática cortesana que continuaron sus hijos y su ceremonia de coronación como Fernando I de Aragón en Zaragoza (1414). Esta marcó un punto de inflexión en las celebraciones de coronación, para un rey que introducía la dinastía Trastámara en Aragón y necesitaba legitimación pública. Su crónica más pormenorizada corresponde a Alvar García de Santa María ${ }^{51}$, refundida para la imprenta en el siglo XVII por Jerónimo de Blancas y en ella se reconoce la similitud de los diseños de ambos eventos que barajan un vocabulario constructivo e ideológico común a todas las cortes europeas: castillos, torres, arcos triunfales, ruedas de la Fortuna. Amén de los contenidos religiosos, el programa artístico de todo el fasto regio, no solo en su coronación ${ }^{52}$, introdujo alegorías de calado intelectual prehumanista que argumentaban el proceso político de su designación. Sin menoscabo de la legitimidad bélica que solía solventarse con la representación de una batalla capital que, en este caso, fue el asalto a Balaguer, capital del condado de su oponente al trono de Aragón, Jaime II de Urgell ${ }^{53}$.

${ }^{51}$ FERRO, Donatella: Le parti inedite della "Crónica de Juan II" di Alvar García de Santa Maria. Venecia, 1972, pp. 97-134.

${ }_{52}$ MASSIP BONET, Francesc: "L'entrada valenciana dels primers Trastàmares", Locvs Amoenvs, 12, 2013-2014, pp. 55-65.

53 DE BLANCAS, Jerónimo: Coronaciones de los Serenissimos Reyes de Aragón... Zaragoza, 1641, pp. 112-113: "E queremos ir passando por las cosas que falló en el camino por las calles donde iva, falló como salia de la Iglesia una Villa fecha de madera sobre carretones, que la llevavan homes, que dentro ivan, en la qual Villa ivan dentro, que parecia verdaderamente que estavan dentro casas, e tejados, e torres, e un poco adelante de la una parte estava un Castillo, e otro de la otra, en cada Castillo estava una como manera de tienda, que eran de madera, e estos Castillos combatian la Villa, e ivan gentes de Armas de fuera de ellos que fazian sus escaramuzas con los de la Villa, e en los Castillos en cada uno iva un engenio, e combatianla con ellos, e lanzavan las pellas tan grandes, como la cabeza de un mozo de diez años, que eran de cuero llenas de borras como pelotas, e tiravan a la Villa con lombardas, e con los ingenios, e los de la Villa tiravan sus truenos, e facian sus artificios para se defender, e esto hizo la Ciudad de Çaragoça a semejanza de como tomò a Balaguer, e por las tiendas entendian los dos Reales que tenia sobre ella, el Rey de la una parte de la tierra, e el Duque de Gandia de la otra parte del rio". 
La recreación del asalto al castillo refleja el momento culminante de la estrategia ofensiva del asedio o sitio. En la lucha contra Granada será la estrategia capital para cualquier victoria a mayor escala. Había que ganar plaza a plaza las fortificaciones y mantenerlas para que hubiera una conquista efectiva del territorio. Aunque en la última fase el uso de la artillería de pólvora marcó ya un nuevo período histórico-militar ${ }^{54}$, con anterioridad, para el asalto a las fortificaciones se aplicaba el contingente más importante de la artillería mecánica medieval: torres, catapultas, arietes, etc. Estamos ante una escenografía festiva, como acabamos de ver, de valor altamente militar que puede recrear episodios concretos de una victoria. Pero el asalto definitivo de un baluarte tiene también un fuerte carácter simbólico y emocional como alegoría de la última lucha hacia la victoria: contra el infiel, contra los vicios, contra la pasión, y cuya verdadera naturaleza la desvelan los personajes participantes: moros, salvajes, damas... Las damas situaban la escena en el contexto del amor cortés, con el juego galante llamado Asalto al castillo de Venus o del Amor, tan exitoso, que formará parte del ciclo iconográfico cortesano que recrea la propia fiesta caballeresca. En los mismos castillos efímeros referidos, las damas tomaban parte activa defendiendo la plaza. Desde las almenas, junto a Venus, lanzaban proyectiles florales mientras los caballeros escalaban inexorables el lienzo de la muralla ficticia. A los pies del castillo las piezas de artillería mecánica que identifican per se la propia acción de la técnica de asalto medieval: el trabuquete que lanza canastos enteros de flores y las ballestas. La dulce capitulación de Amor se representaba con la entrega de las llaves del castillo que los vencedores aceptaban rendidos a sus pies como humildes vasallos (Figura 7). Así, este recurso festivo de la inversión de la norma, plenamente medieval, escenificaba la propia ética del amor cortés en su marco público más incomparable bajo genuina estética guerrera.

Como hemos podido comprobar, el castillo preside la actividad festiva caballeresca. Es el atributo clave de este repertorio escenográfico y recibe el máximo tratamiento artístico. El castillo es el punto neurálgico del poder jurídico-militar medieval, es la sede del orden feudal. Por tanto, su presencia durante el festejo es símbolo de legitimidad estamental tanto regia como nobiliaria. La fiesta caballeresca en sí, es exactamente una apología artística del mismo concepto en clave política, pues su función propagandística obliga a realizar un ejercicio estético de la ostentación del poder. Paradójicamente, una vez levantadas en el siglo XIV las condenas religiosas sobre el fasto caballeresco, este permitió canalizar una importante cuota de violenta cultura guerrera hacia un ejercicio alegórico de sí mismo, a través de recepciones, homenajes, agasajos y espectáculos que hoy sientan las bases de la diplomacia actual. Toda esta recreación ficticia liberaba

${ }^{54}$ GARCÍA FITZ, Francisco: "Las guerras de cada día”, La Castilla del siglo XIV. Edad Media. Revista de Historia, 8, 2007, pp. 169-170. 
múltiples tensiones que, de otra manera, se hubieran visto avocadas a una resolución armada del conflicto.

Estos castillos efímeros con torres de distintos tamaños tenían todo un repertorio de formatos en las máquinas de asalto medievales. Unas, de gran tamaño y altura, denominadas bastidas y utilizadas en funciones defensivas como barreras móviles u ofensivas, cuando avanzaban lenta pero implacablemente sobre rodamientos, empujadas por cantidades ingentes de peones hasta alcanzar la muralla enemiga (Figura 8). Otras, más pequeñas, se movilizaban sobre las mencionadas carretas $^{55}$. Cada una de ellas tenía una función y nomenclatura precisa ${ }^{56}$. Todas, diseñadas y calculadas para ejercer su cometido con precisión. Estructuras que podían utilizarse desnudas como cadalsos verticales o "vestidas" pintadas con lienzos o sobre sus propios "cueros crudos" imitando labor de cantería como las torres de estos castillos efímeros con gran capacidad de alojamiento que nos describen las crónicas.

En cuanto a sus ingenieros, en Sevilla, sus competencias aparecen adscritas al gremio de los alarifes en las Ordenanzas del siglo XIII, como consta en el Libro del Peso...: "entendidos de fazer engenios". En los libros de cuentas de Sancho IV se relacionan los "maestros de los ingenios". Pedro I en 1364 encargó nuevos ingenios a maestros carpinteros del reino de Murcia. Aún, en las ordenanzas sevillanas de 1527, los carpinteros de lo blanco tienen que saber hacer "aquellos ingenios destinados a combatir ciudades y fortalezas". El reconocimiento de la maestría de los ingenieros lombardos se repite en las fuentes históricas y en la literatura medieval castellana y europea ${ }^{57}$. La tradicional auctoritas de la tratadística y poliorcética militar desde la Antigüedad la detentaban en la Edad Media el De Architectura de Vitruvio (año 15 a.C.) y, sobre todo, el Epitoma rei militaris de Vegecio (siglo IV d.C.), obra de cabecera para la institución. Don Juan Manuel escribió el Libro de los engennos, perdido en el incendio de Pañafiel. La ausencia de tratados técnicos medievales se explica por la propia dinámica restringida de formación y transmisión del conocimiento gremial. García Fitz destaca la influencia del Thexaurus regis Franciae... en la tratadística del siglo XV. Escrito en 1335, precisamente por un lombardo, Guido da Vigevano, para Felipe VI de Francia. Es un método de actuación para solventar retos médicos y militares durante una Cruzada y el tratado de máquinas de guerra más completo hasta ese momento. Nos interesa destacar en él, su estudio en economía de medios:

${ }_{55}$ CONTAMINE, Philippe: La guerra en la Edad Media, op. cit., p. 129.

${ }^{56}$ ALFONSO X, EL SABIO: Las Siete Partidas, II, XXIII, 24, op. cit., p. 314.

57 CÓMEZ RAMOS, Rafael: Las empresas artísticas de Alfonso X el Sabio. Sevilla, 1979, pp. 35-38; y CÓMEZ RAMOS, Rafael: Los constructores de la España medieval. $3^{\text {a }}$ ed. Sevilla, 2009, pp. 81, 83 y 116-118. 
materiales, transporte e instalación, diseñando piezas prefabricadas, plegables o desmontables ${ }^{58}$.

\section{IV}

En definitiva, la semejanza en las fuentes escritas y gráficas del diseño escénico del aparato lúdico-festivo caballeresco como parte de un repertorio común a toda la Cristiandad. El alto coste de su magnificencia estructural y compositiva $\mathrm{y}$, sobre todo, su imperiosa necesidad de seguridad, obligaba a manejar la necesaria optimización de los recursos técnicos y económicos con un abanico básico de elementos probados y estables, transportables y con un plazo mínimo de montaje, es decir, prefabricados que ya estaba resuelto en las máquinas de asalto. Una vez instalado y revestido con su rica cubierta textil, el puntual tratamiento temático del festejo daría acogida a un nuevo espectáculo, donde la artillería mecánica formaba parte del attrezzo. La parafernalia militar y política era una dotación necesaria y común para el ejercicio del poder de la monarquía y los grandes magnates bajomedievales. Por tanto, debía resolverse mediante una logística general y, por ello, comparten suministros, pertrechos y equipo técnico humano. Como el gran aparato que movilizó el maestre de Calatrava, don Pedro Girón, en su intento fallido de esposar a la infanta Isabel, futura reina de Castilla ${ }^{59}$.

Fecha de recepción: 25 de octubre de 2017

Fecha de aceptación: 12 de abril de 2018

${ }^{58}$ GARCÍA FITZ, Francisco: "Tecnología, literatura técnica y diseño de máquinas de guerra durante la Baja Edad Media occidental: El Thexaurus Regis Franciae Acquisitionibus Terrae Santae de Guido Da Vigevano (1335)", Anuario de Estudios Medievales, 41/2, 2011, pp. 841-862.

59 DE VALERA, Diego: Memorial de diversas hazañas, Cap. XXXVI, op. cit., p. 118: "La qual como fuese certificada del propósito con quel maestre venía, e con grande aparato, no solamente de guerra mas de corte, e con grandes aparejos para fazer justas y torneos e todas las fiestas que se acostunbran fazer en las bodas de los grandes príncipes". 


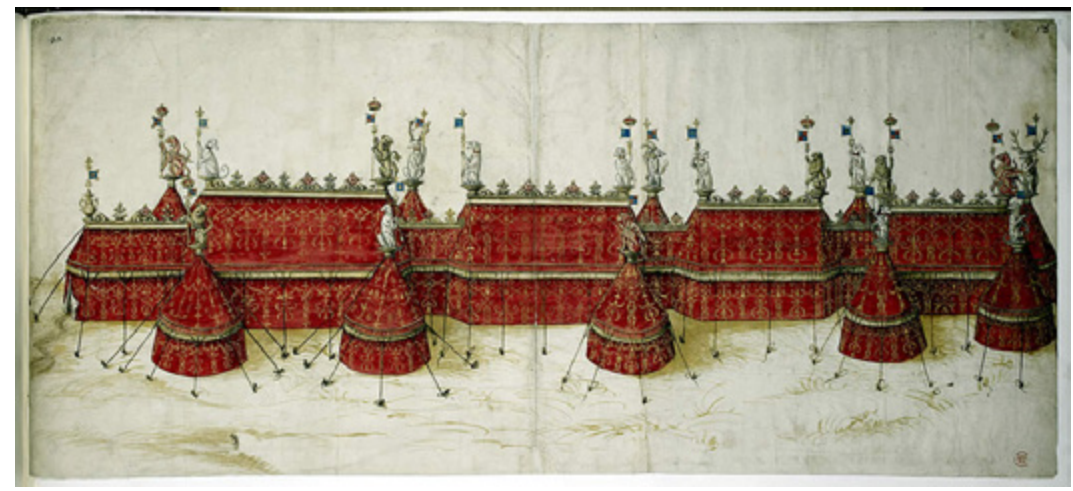

Figura 1. Diseño de pabellones, Campo de los paños de oro (1520), Ms. Cotton, Augustus III, f. 18, British Library, Londres.

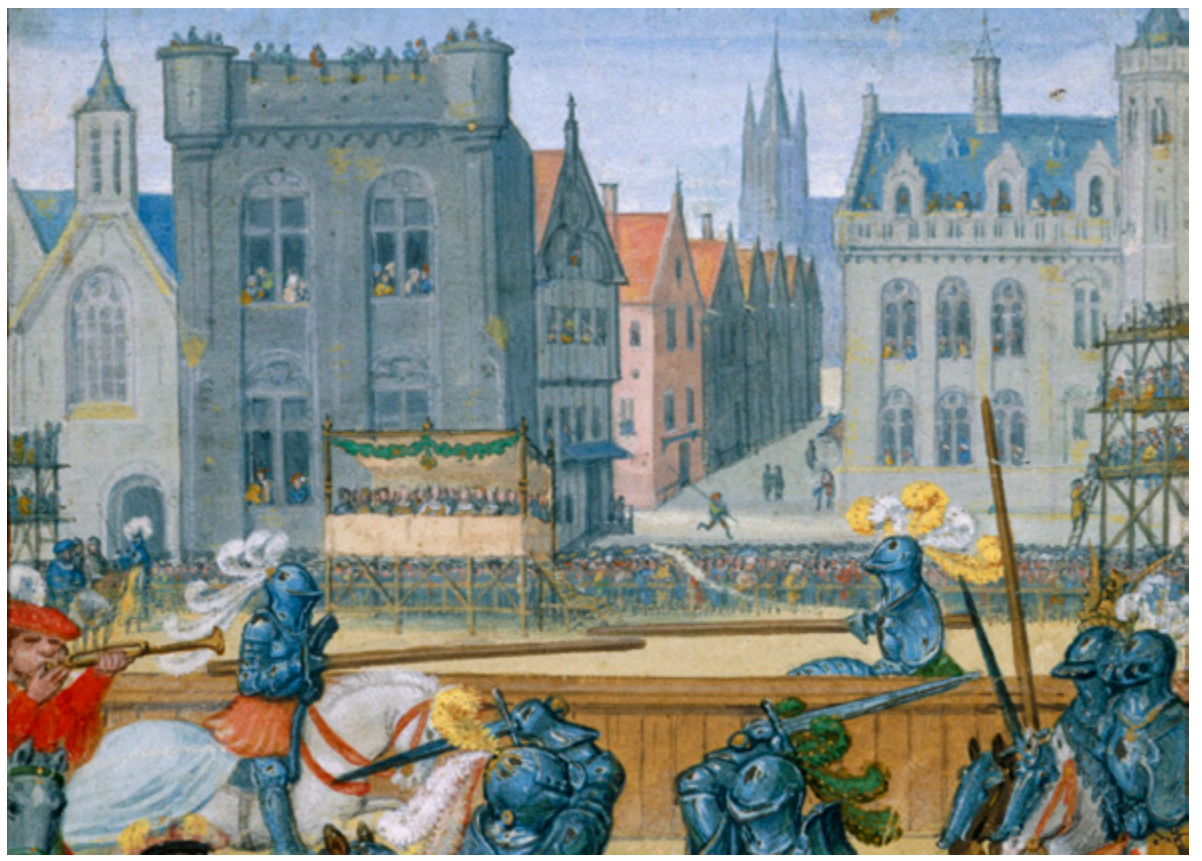

Figura 2. Detalle de la altura de los cadalsos, Libro de horas de Simón Bening (1520-1530), Mes de junio, Ms. Add. 24098, f. 23v, British Library, Londres. 


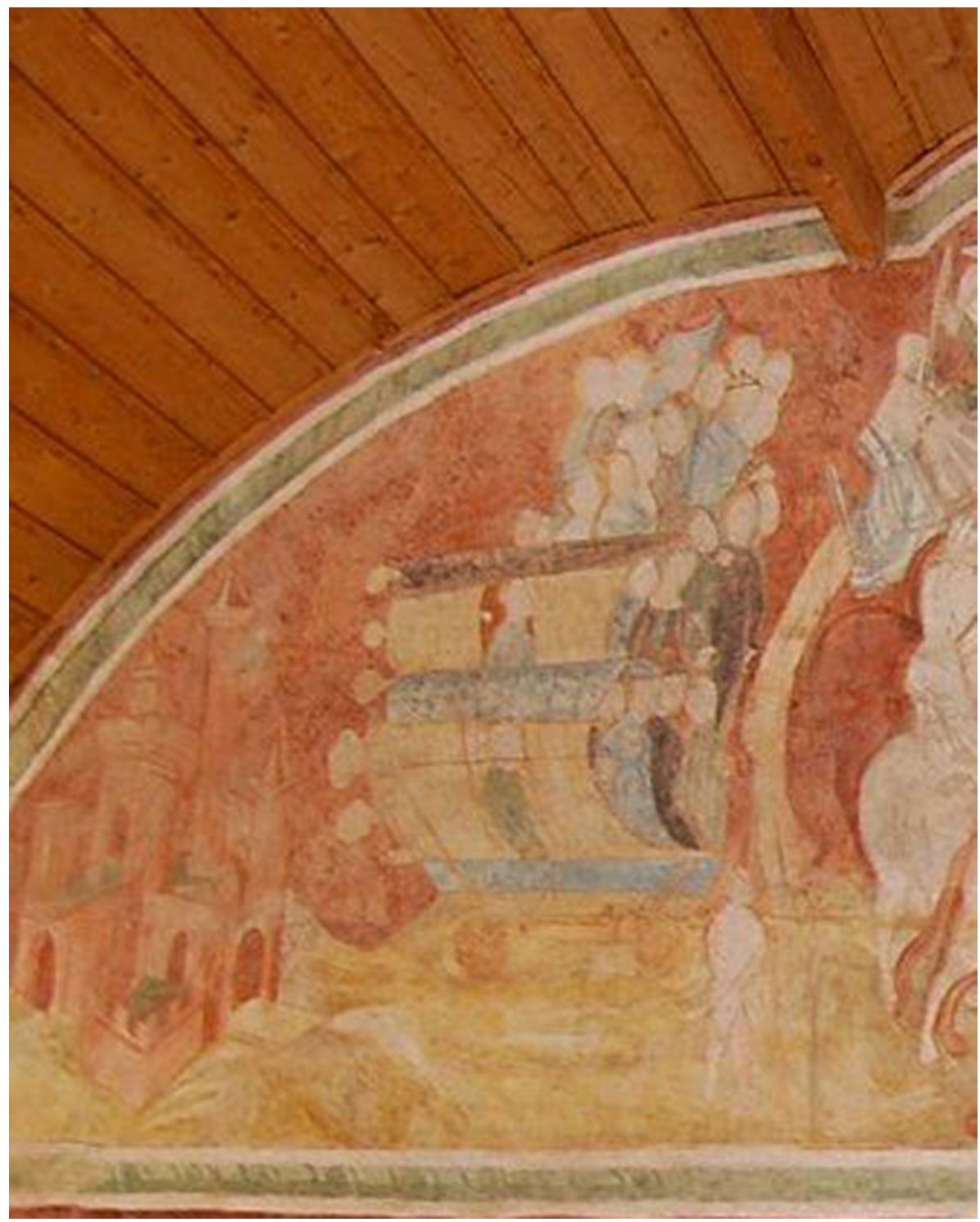

Figura 3. Detalle de tribuna móvil, Torneo de las mazas, siglo XIV, Sala de las Parejas, castillo Runkelstein, Bolzano. 


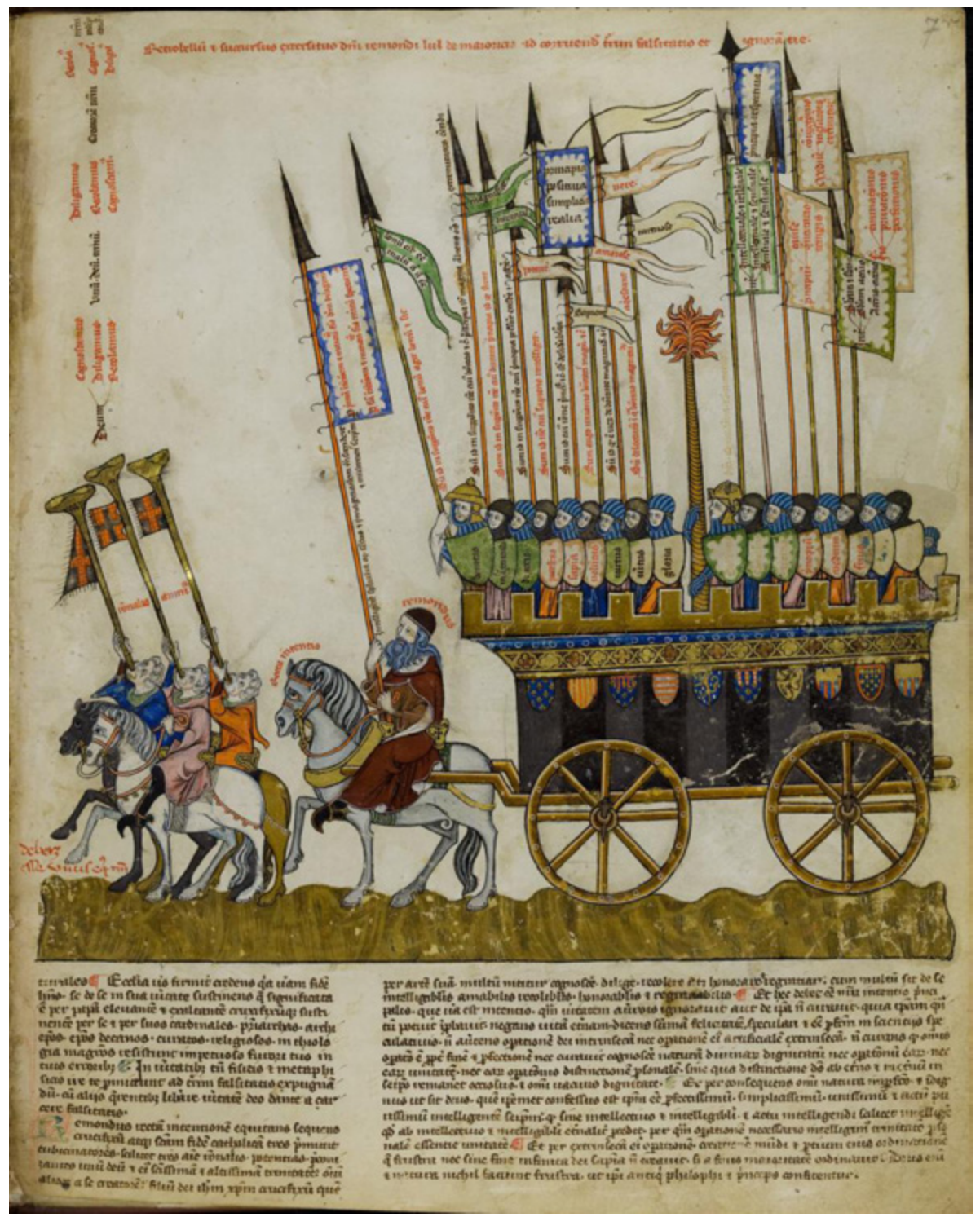

Figura 4. Thomas Le Myésier, Breviculum ex artibus Raimundi Lulli electum, 1322, St. Peter perg. 92, f. 7r, BLB - Badische Landes Bibliothek, Karlsruhe. 


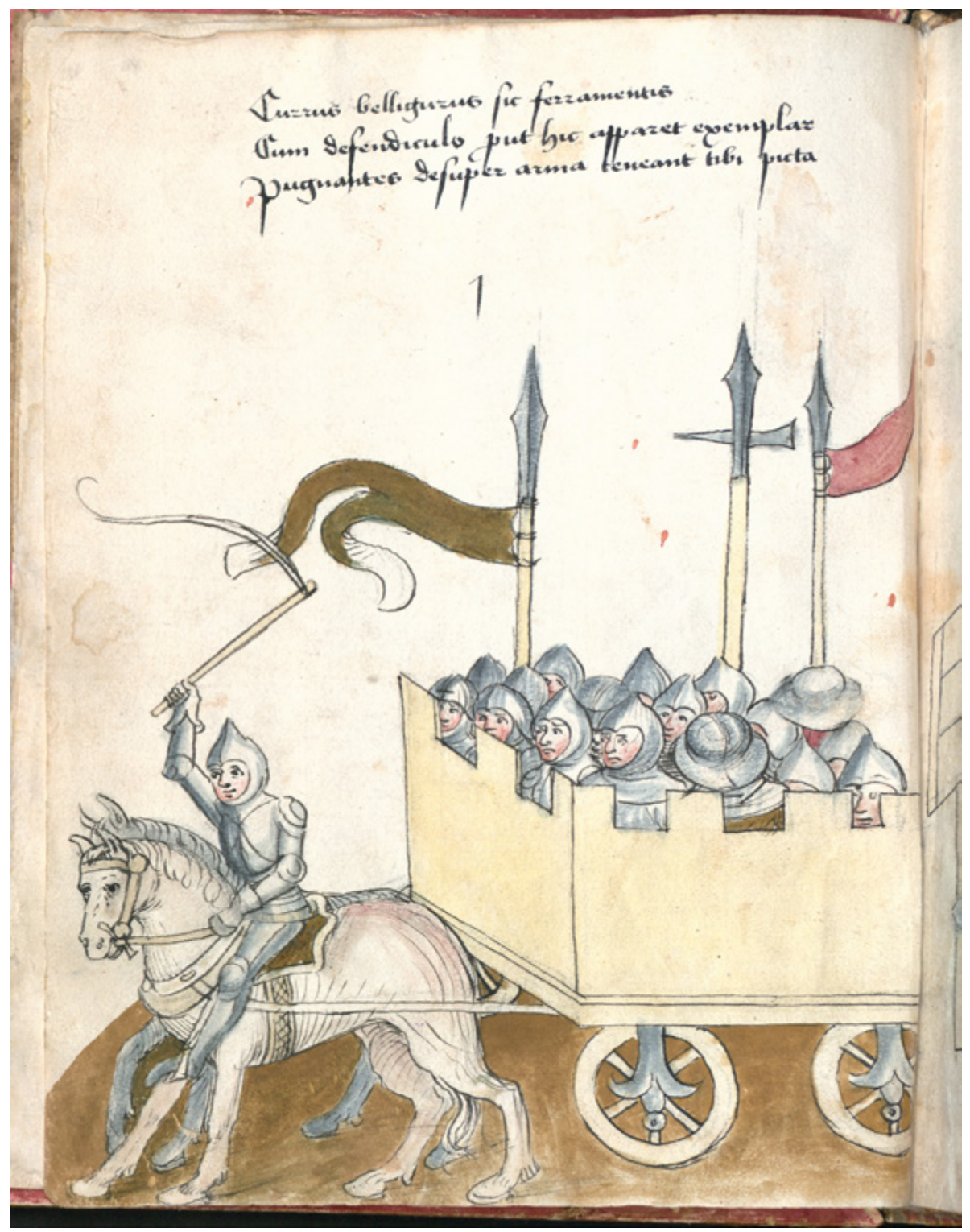

Figura 5. Konrad Kyeser, Bellifortis, c. 1430, Ms. 30150, f. 8, BSB-Bayerischen Staatsbibliothek Bavarian, Münich. 


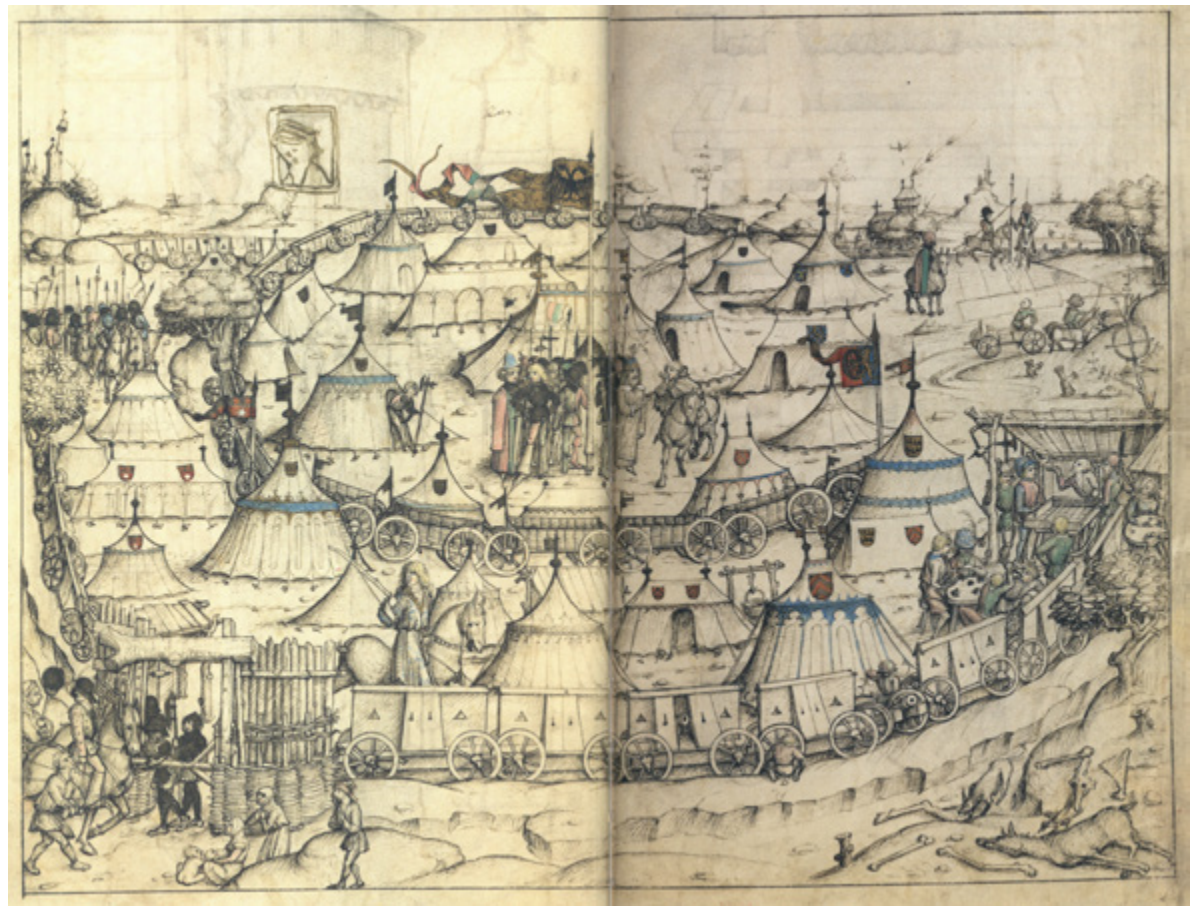

Figura 6. Campamento, The Medieval Housebook of Wolfegg, 1475-1500, ff. 53r-53r1, colección particular. 


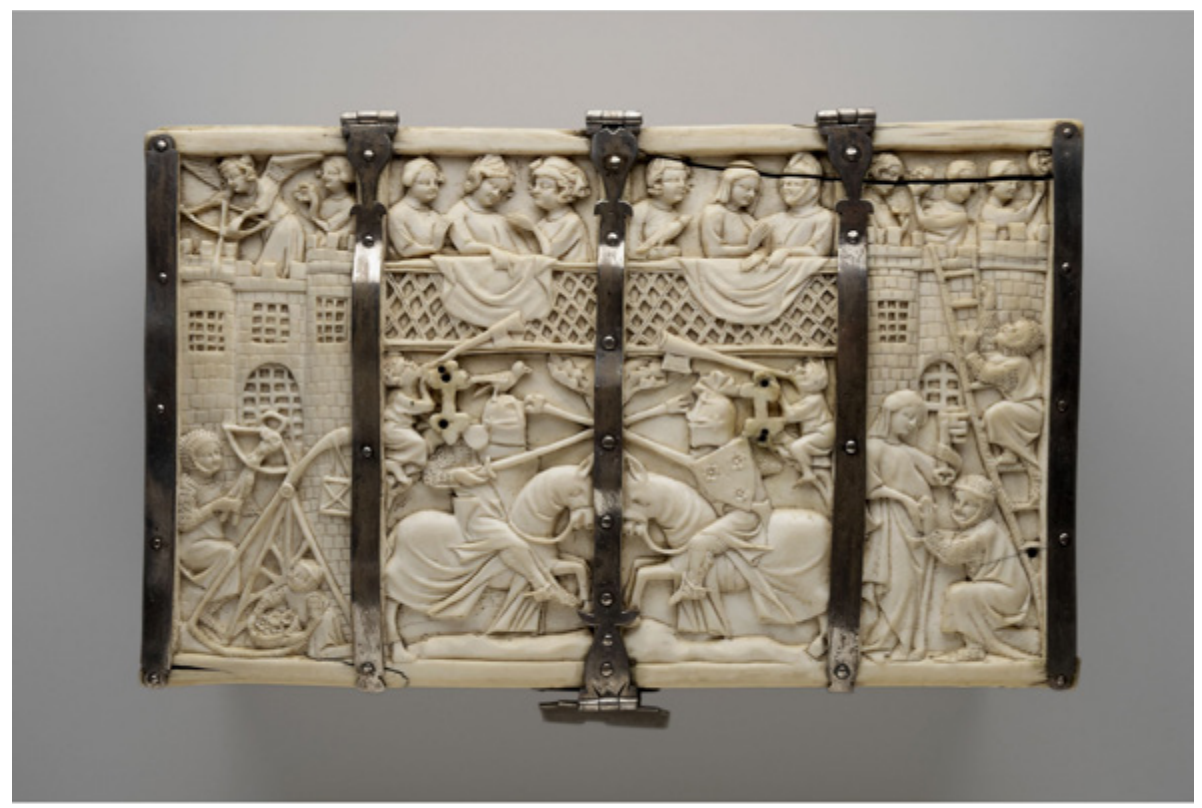

Figura 7. Justa (registro central) y Asalto al castillo del Amor (laterales), caja de marfil, escuela francesa, siglo XIV, British Museum, Londres. 


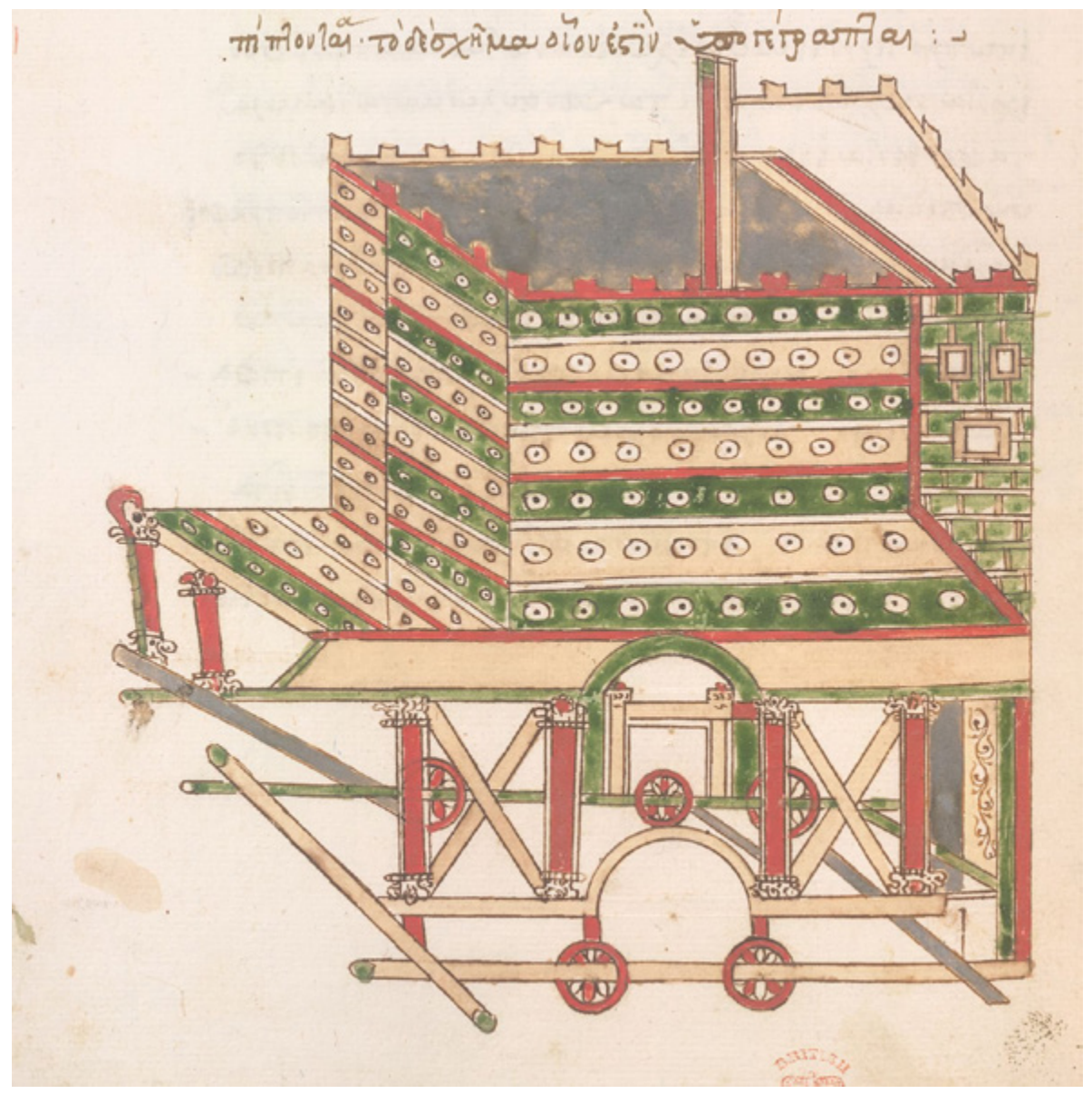

Figura 8. Torre de asalto, Bitonis, De constructione bellicarum machinarum, Venecia, 1545, Ms. Burney 69, f. 12v, British Library, Londres. 